\title{
Comparison of Line Spread Test (LST) Results of Eight Different types of Thickeners Performed on Vegetable Menus (Salmon and Vegetable with Egg Sauce) that can be Crushed with Gums
}

\author{
Mayumi Hirabayashi ${ }^{1}$ and Naomi Katayma ${ }^{1,2 *}$ \\ ${ }^{1}$ Graduate School of Food Science and Nutrition, Nagoya Women's University, Japan \\ ${ }^{2}$ Faculty of Health Sciences, Department of Health and Nutrition, Nagoya Women's University, Japan
}

\begin{abstract}
Japan is a super-aging society. Therefore, there is a shortage of welfare facilities that can accept elderly people for the number of elderly people who need long-term care. Then, in many cases, it is necessary to provide long-term care at home. One of the problems that caregivers have when they are at home is nursing care food. Creating three meals daily is physically, mentally, and economically burdensome for the caregiver. So, this research, we used a commercially available universal design food (UDF), and by combining it with a commercially available thickener, we aimed to create a nursing care food menu that ca be created even at home. Among the universal design foods (UDF) on the market, the method is crushable with a tooth gums, salmon and vegetable egg sauce, $(100 \mathrm{~g}$ retort pack, sold for190 Japanese yen (1.73 USD). The nutritional value is $67 \mathrm{kcal}$ of energy, $4.1 \mathrm{~g}$ of protein, $1.3 \mathrm{~g}$ of lipid, $9.3 \mathrm{~g}$ of carbohydrate, and $0.8 \mathrm{~g}$ of salt equivalent per $100 \mathrm{~g}$. After that, the viscosity was examined 30 seconds and 5 minutes later, and a meal that was easy to swallow was prepared. A line spread teat (LST) was performed to measure the viscosity of this food. The LST values was statistically compared. Using Excel Statistics 2010 (manufactured by SSRI) as the statistical software, if there is no significant difference after the $\mathrm{F}$ test in the comparison between 30 seconds and 5 minutes in each thickener, a parametric test, the student- $\mathrm{t}$ test, was performed. Using the test, if there was a significant difference in the F test, a nonparametric test, the wilcoxon test, was performed. As a result, it was found that the viscosity of all eight types of thickeners decreased with time, but the A thickener (dextrin (in Japan)/Thickening polysaccharide Potassium chloride Sweetener (Sucralose)) was the most stable of the eight types Since eating takes time, stability is required as much as possible. Thickener A had the best compatibility with the foods on the market this time in the future, we will continue to measure LST values for many foods and that can be used in ordinary households.
\end{abstract}

KEYWORDS: Line spread test (LST); Universal design food (UDF); Thickener; Crushed with gums

ABBREVIATIONS: LST: Line Spread Test; UDF: Universal Design Food

\section{INTRODUCTION}

Considering that the number of long-term cares at home will increase in the future, research on long-term care foods that can be made at home will become more important. Looking at the number of facilities for the elderly in Japan by type, according to the overview of the 2017 Social Welfare Facility Survey, the largest number is elderly homes by paid, and the number is 13,525 , which is charged with long-term care. The number included 3 types of homes for the elderly, long-term care nursing homes by paid, home-based nursing homes by paid, and healthy nursing homes by paid. The next most common is group homes for people with dementia, with 12,124 facilities, and the third most common is the low-cost, public nursing homes for the elderly with 7,891 facilities.
Quick Response Code:

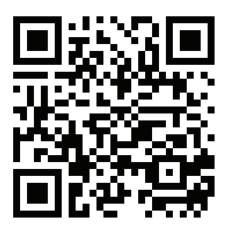

Address for correspondence: Naomi Katayma, Faculty of Health Sciences, Department of Health and Nutrition, Nagoya Women's University, 3-40, Shioji-cyo, Mizuho-ku, Nagoya city, Aichi, 467-8610, Japan

Received: November 8, $2021 \quad$ Published: November 24, 2021

How to cite this article: Mayumi H, Naomi K. Comparison of Line Spread Test (LST) Results of Eight Different types of Thickeners Performed on Vegetable Menus (Salmon and Vegetable with Egg Sauce) that can be Crushed with Gums. 2021- 3(6) OAJBS.ID.000351. DOI: 10.38125/ OAJBS.000351 
However, looking at the number of people, the number of special elderly nursing homes was 540,000, which was the largest number of residents. From this, it is expected that the demand for long-term care food will increase more and more in the future.

Dietary protein supplementation is important to prevent sarcopenia [1,2] and flail [3-9] in the nutritional status of the elderly. A thickened diet is required for safe dietary intake [10]. In the case of long-term care, a concentrated liquid diet may be used to prevent undernutrition. At that time, when the swallowing function is weakened, thickening is performed on foods and meals containing a large amount of water in order to avoid aspiration pneumonia [11-13]. Measuring viscosity before serving a meal is necessary for a safe meal serving [14-16].

\section{PURPOSE}

Therefore, in this study, aiming at a long-term care food that can be prepared at home, we started by using a commercially available product with uniform quality and adding viscosity to the food by adding a commercially available thickener to feed it. We aimed to create a long-term care food that is difficult to swallow and adheres to the swallowing pyramid advocated by the Swallowing
Rehabilitation Society. As already reported in previous studies, this study uses two types of thickeners, mainly dextrin (in Japan)/ Thickening polysaccharide and Dietary fiber), and among multiple commercially available universal design food (three types) that do not need to be chewed. LST tests were performed using each of the three types of thickeners that can be crushed with the gums and three types that can be easily chewed, and results were obtained. Therefore, in this study, we used eight types of thickeners that can be obtained at nearby pharmacies at home and used a thickener for salmon and vegetable egg sauce, which are commercially available vegetables that can be crushed with gums. We decided to compare the viscosities of the above using the LST test.

\section{MATERIALS AND METHODS}

\section{Commercially Available Thickener}

Eight products commercially available in pharmacies were used as over-the-counter thickeners. Since it is a thickener, the nutritional components are shown in Table $1 \& 2$. All eight types of thickeners were dextrin-based thickeners. The price was in the price range that can be purchased by ordinary households $(100 \mathrm{~g}$ is within 1000 Japanese yen).

Table 1: Nutritional values of eight types of thickeners (per 100 grams).

\begin{tabular}{|c|c|c|c|c|c|c|}
\hline Per $100 \mathrm{~g}$ & $\begin{array}{c}\text { Energy } \\
\text { kcal }\end{array}$ & $\begin{array}{c}\text { Protein } \\
\text { g }\end{array}$ & $\begin{array}{l}\text { Lipids } \\
\qquad \mathrm{g}\end{array}$ & $\begin{array}{c}\text { Sugar } \\
\text { g }\end{array}$ & $\begin{array}{c}\text { Dietary Fiber } \\
\text { g }\end{array}$ & $\begin{array}{c}\text { Salt Equivalent } \\
\mathrm{g}\end{array}$ \\
\hline $\mathrm{A}$ & 263 & $0 \sim 10$ & $0 \sim 10$ & 64.3 & 23.5 & 1.4 \\
\hline $\mathrm{B}$ & 261 & 0.7 & 0 & 46 & 37 & 2.4 \\
\hline $\mathrm{C}$ & 292 & 0.5 & 0 & 60.5 & 23.8 & 3.9 \\
\hline $\mathrm{D}$ & 270 & 0.5 & 0 & 67.5 & 21.9 & 2.5 \\
\hline E & 290 & 0.5 & 0 & 59.6 & 24.9 & 3.7 \\
\hline $\mathrm{F}$ & 230 & $0.3 \sim 1.0$ & 0 & 54.9 & 34.3 & 4.7 \\
\hline G & 288 & $0.4 \sim 1.7$ & $0 \sim 0.3$ & 54 & 33 & 4.5 \\
\hline $\mathrm{H}$ & 230 & $0.3 \sim 1.0$ & 0 & 60.5 & 34.3 & 4.7 \\
\hline
\end{tabular}

Table 2: Ingredients of eight kinds of thickeners (per 100g).

\begin{tabular}{|c|c|c|c|c|}
\hline $\begin{array}{l}\text { Per } \\
100 g\end{array}$ & $\begin{array}{l}\text { Individual wrapping (price)g } \mathrm{x} \\
\text { wrapping }=\text { Yen }\end{array}$ & $\begin{array}{l}\text { Per 100g } \\
\text { Price Yen }\end{array}$ & lngredients Name & $\begin{array}{l}\text { Price }(\$) \\
1 \$=110 ¥\end{array}$ \\
\hline A & $3 g$ x 50 wrapping = $1274 ¥$ & $849 ¥$ & $\begin{array}{c}\text { dextrin (in Japan)/ Thickening polysaccharide, Potassium } \\
\text { chloride, Sweetener (Sucralose) }\end{array}$ & $11.6 \$$ \\
\hline B & $1.5 \mathrm{~g}$ x 50 wrapping = 728¥ & $971 ¥$ & $\begin{array}{c}\text { dextrin (in Japan)/ Thickening polysaccharide, Potassium } \\
\text { chloride }\end{array}$ & $6.6 \$$ \\
\hline $\mathrm{C}$ & $1.5 \mathrm{~g} \times 50$ wrapping $=537 ¥$ & $716 ¥$ & dextrin (in Japan)/ Thickening polysaccharide, $\mathrm{pH}$ adjuster & $4.9 \$$ \\
\hline $\mathrm{D}$ & $3 \mathrm{~g} \times 50$ wrapping= $1390 ¥$ & $927 ¥$ & $\begin{array}{c}\text { dextrin (in Japan), Xanthan gum, Calcium lactate, } \\
\text { Trisodium citrate }\end{array}$ & $12.6 \$$ \\
\hline $\mathrm{E}$ & $2.5 \mathrm{~g} \times 50$ wrapping = $1130 ¥$ & $904 ¥$ & dextrin (in Japan)/ Thickening polysaccharide, $\mathrm{pH}$ adjuster & $10.3 \$$ \\
\hline $\mathrm{F}$ & $3 \mathrm{~g} \times 50$ wrapping = $1490 ¥$ & $993 ¥$ & $\begin{array}{l}\text { dextrin (in Japan)/ Thickening polysaccharide, (CMC), } \\
\text { Sodium gluconate, Magnesium chloride }\end{array}$ & $13.5 \$$ \\
\hline $\mathrm{G}$ & $2 \mathrm{~g} \times 30 \mathrm{wrapping}=476 ¥$ & $793 ¥$ & dextrin (in Japan)/ Thickening polysaccharide, Emulsifier & $4.3 \$$ \\
\hline $\mathrm{H}$ & $3 \mathrm{~g} \times 50$ wrapping = $1490 ¥$ & $993 ¥$ & $\begin{array}{l}\text { dextrin (in Japan)/ Thickening polysaccharide (CMC), } \\
\text { Sodium gluconate, Magnesium chloride }\end{array}$ & $13.5 \$$ \\
\hline
\end{tabular}

\section{Commercially Available Long-Term Care Food}

One product forms the crushable by gums category of universal design foods on the market, salmon and vegetable egg sauce, was used. All are sold in $100 \mathrm{~g}$ retort pouches for 190 Japanese Yen (1.73 USD).
The nutrition al value was $67 \mathrm{Kcal}$ of energy, $4.1 \mathrm{~g}$ protein, $1.3 \mathrm{~g}$ of fat, $9.3 \mathrm{~g}$ of carbohydrate, and $0.8 \mathrm{~g}$ of salt equivalent per $100 \mathrm{~g}$.

\section{Preparation of Sample (Food with Thickener)}

One food was prepared into 5 samples. 1 . The viscosity of the food itself was measured as it was without any modification. 2 . The 
food was crushed for 20 seconds using a mixer, pulverized into a liquid state, and the viscosity was measured. 3 . The viscosity was measured after adding $1 \mathrm{~g}$ of thickener $(\mathrm{A}, \mathrm{B}, \mathrm{C}, \mathrm{D}, \mathrm{E}, \mathrm{F}, \mathrm{G}, \mathrm{H})$ to the food (100g) ground for 20 seconds with a mixer and stirring for 5 minutes. 4 . The viscosity was measured after adding $2 \mathrm{~g}$ of thickener $(\mathrm{A}, \mathrm{B}, \mathrm{C}, \mathrm{D}, \mathrm{E}, \mathrm{F}, \mathrm{G}, \mathrm{H})$ to the food $(100 \mathrm{~g})$ ground for 20 seconds with a mixer and stirring for 5 minutes. 5 . The viscosity was measured after adding $3 \mathrm{~g}$ of thickener $(\mathrm{A}, \mathrm{B}, \mathrm{C}, \mathrm{D}, \mathrm{E}, \mathrm{F}, \mathrm{G}, \mathrm{H})$ to the food $(100 \mathrm{~g})$ ground for 20 seconds with a mixer and stirring for 5 minutes.

\section{Viscosity Measurement Method}

The viscosity of each sample was measured using line spread test (LST) starter kit manufactured by SARAYA. The measurement criteria are as follows. The viscosity was measured at room temperature of 24 ? ?. The test was repeated 3 times and the average value was calculated.

1) Place the sheet on a horizontal surface and place a ring with an inner diameter of $30 \mathrm{~mm}$ in the center of the concentric circles.

2) Add up to 1 tablespoon $(20 \mathrm{ml})$ of the thickening liquid to be measured and let stand for 30 seconds.

3) Lift the ring horizontally, and after 30 seconds, measure the spread distance of the solution at 1-6 points. Let the average value be the LST value.

4) After leaving it for 5 minutes, the spread distance of the solution was measured again at 6 points, and the average value was taken as LST

\section{Viscosity Criteria}

There are three levels of classification by LST values. The first stage is a thin thickening with a viscosity that falls within $43-36 \mathrm{~mm}$
(50 150mPa $\bullet$ s). The property is that when you tilt the spoon, it runs down smoothly. The second stage is an intermediate thickening with a viscosity that falls within $36-32 \mathrm{~mm}(150 \sim 300 \mathrm{mPa} \bullet \mathrm{s})$. The property is that when you tilt the spoon, it flows like a pottage. The third stage is a thick thickening with viscosity that falls within 32$30 \mathrm{~mm}(300 \sim 500 \mathrm{mPa} \bullet \mathrm{s})$. Even if the spoon is tilted, the shape is kept moderate, and it is difficult to flow.

\section{Statistical Processing}

This study was statistically processed using statistical processing software, Excel 2010 (SSRI Co., Ltd.). The date to be compared were first tested for the normal distribution by F-test. For comparison between correlation data, paired Student-t test was used for normal distribution data. The Wilcoxon test was used for non-normally distributed data. For comparisons between uncorrelated data, the student-t test, which is not bear to the normal distribution, was used. The Mann-Whitney test was used for the non-normal distribution.

\section{RESULTS}

\section{LST Test Results using 8 Types of Thickeners}

The LST value obtained as it is without adjustment and the LST value obtained after 20 seconds in the mixer, with the salmon and vegetable egg sauce, which is a commercially available UDF that can be crushed with the gums, used this time. Table 3 shows the results of the LST values measured by adding $1 \mathrm{~g}, 2 \mathrm{~g}$, and $3 \mathrm{~g}$ of each of eight types of thickeners. For all thickeners, the LST value was higher after 5 minutes than after 30 seconds, but thickener A had the highest viscosity. Other than that, the thickeners F, B, D, H, E, G, and $\mathrm{C}$ had the highest viscosities in that order.

Table 3: LST results with eight thickeners (Crushable with gums: salmon and vegetable with egg sauce).

\begin{tabular}{|c|c|c|c|c|c|c|c|c|c|c|c|}
\hline \multirow{2}{*}{$\begin{array}{l}\text { Thickener } \\
\text { Name }\end{array}$} & \multirow{2}{*}{$\begin{array}{c}\text { Points } \\
\begin{array}{c}3 \mathrm{X} \\
\text { (6points) }\end{array}\end{array}$} & \multicolumn{2}{|c|}{ No Modify } & \multicolumn{2}{|c|}{ After Mixing } & \multicolumn{2}{|c|}{ Add Thickener $1 \mathrm{~g}$} & \multicolumn{2}{|c|}{ Add Thickener $2 \mathrm{~g}$} & \multicolumn{2}{|c|}{ Add Thickener $3 g$} \\
\hline & & $\begin{array}{l}\text { After } 30 \\
\text { Seconds }\end{array}$ & $\begin{array}{c}\text { After } 5 \\
\text { Minutes }\end{array}$ & $\begin{array}{l}\text { After } 30 \\
\text { Seconds }\end{array}$ & $\begin{array}{c}\text { After } 5 \\
\text { Minutes }\end{array}$ & $\begin{array}{l}\text { After } 30 \\
\text { Seconds }\end{array}$ & $\begin{array}{c}\text { After } 5 \\
\text { Minutes }\end{array}$ & $\begin{array}{l}\text { After } 30 \\
\text { Seconds }\end{array}$ & $\begin{array}{c}\text { After } 5 \\
\text { Minutes }\end{array}$ & $\begin{array}{l}\text { After } 30 \\
\text { Seconds }\end{array}$ & $\begin{array}{c}\text { After } 5 \\
\text { Minutes }\end{array}$ \\
\hline \multirow{2}{*}{$\mathrm{A}$} & $\begin{array}{l}\text { Average } \\
\text { Value }\end{array}$ & 28.6 & 31.3 & 33.4 & 35 & 15.5 & 16.6 & 13.6 & 14.6 & 12.1 & 13.1 \\
\hline & $\begin{array}{l}\text { Standard } \\
\text { Deviation }\end{array}$ & 4.9 & 5.1 & 2.2 & 2.4 & 13.9 & 15 & 11.2 & 12.2 & 8.9 & 9.4 \\
\hline \multirow{2}{*}{ B } & $\begin{array}{l}\text { Average } \\
\text { Value }\end{array}$ & 30.3 & 33.1 & 33.8 & 35.3 & 27.4 & 28.7 & 21.7 & 23.4 & 20.8 & 21.7 \\
\hline & $\begin{array}{l}\text { Standard } \\
\text { Deviation }\end{array}$ & 6 & 5 & 2.4 & 2.6 & 2.1 & 1.9 & 3.6 & 3.6 & 5.7 & 6.2 \\
\hline \multirow{2}{*}{$\mathrm{C}$} & $\begin{array}{l}\text { Average } \\
\text { Value }\end{array}$ & 28.5 & 31.1 & 31.3 & 32.7 & 312 & 33.7 & 24.3 & 26.6 & 20.3 & 21.7 \\
\hline & $\begin{array}{l}\text { Standard } \\
\text { Deviation }\end{array}$ & 4.5 & 5.1 & 3 & 3.3 & 1.4 & 1.7 & 1.8 & 1.9 & 2.9 & 3.5 \\
\hline \multirow{2}{*}{$\mathrm{D}$} & $\begin{array}{l}\text { Average } \\
\text { Value }\end{array}$ & 26.8 & 29.7 & 32.6 & 34.3 & 28.7 & 31 & 28 & 30.8 & 20.1 & 22.3 \\
\hline & $\begin{array}{l}\text { Standard } \\
\text { Deviation }\end{array}$ & 3.3 & 3.9 & 1.3 & 1.5 & 2.8 & 2.9 & 1.6 & 1.9 & 3.6 & 3.5 \\
\hline \multirow{2}{*}{$\mathrm{E}$} & $\begin{array}{l}\text { Average } \\
\text { Value }\end{array}$ & 28.1 & 31.3 & 34 & 35.7 & 29.5 & 32.2 & 28.1 & 31.1 & 22 & 23.4 \\
\hline & $\begin{array}{l}\text { Standard } \\
\text { Deviation }\end{array}$ & 5.8 & 6.7 & 3 & 3.2 & 2.4 & 2.4 & 1.8 & 1.4 & 1.9 & 2.3 \\
\hline
\end{tabular}




\begin{tabular}{|c|c|c|c|c|c|c|c|c|c|c|c|}
\hline \multirow{2}{*}{$\mathrm{F}$} & $\begin{array}{c}\text { Average } \\
\text { Value }\end{array}$ & 29.2 & 317 & 33.6 & 35.1 & 26.3 & 28.3 & 23.4 & 24.7 & 19.7 & 20.7 \\
\cline { 2 - 12 } & $\begin{array}{c}\text { Standard } \\
\text { Deviation }\end{array}$ & 6.2 & 6.4 & 2.1 & 2.3 & 2.7 & 2.9 & 3.3 & 3.5 & 4.6 & 5.1 \\
\hline \multirow{2}{*}{$\mathrm{G}$} & $\begin{array}{c}\text { Average } \\
\text { Value }\end{array}$ & 27.7 & 30.1 & 33.8 & 35.5 & 30.3 & 32.8 & 21.6 & 23.1 & 20.1 & 22 \\
\cline { 2 - 16 } & $\begin{array}{c}\text { Standard } \\
\text { Deviation }\end{array}$ & 3.8 & 4.6 & 1.5 & 1.8 & 1.4 & 1.4 & 4.4 & 52 & 3.5 & 4.8 \\
\hline \multirow{3}{*}{$\mathrm{H}$} & $\begin{array}{c}\text { Average } \\
\text { Value }\end{array}$ & 29.9 & 31.9 & 34.9 & 36.3 & 28.4 & 30.4 & 21.8 & 22.6 & 21.7 & 22.7 \\
\cline { 2 - 15 } & $\begin{array}{c}\text { Standard } \\
\text { Deviation }\end{array}$ & 4.4 & 3.8 & 2.4 & 2.4 & 2.1 & 2.1 & 4.3 & 4.6 & 2.8 & 3.2 \\
\hline
\end{tabular}

Statistical Processing Results of LST Test using 8 Types of Thickeners

Comparison of LST values after 30 seconds and 5 minutes in salmon and vegetable egg sauce that can be crushed with gums UDF on the market before adding thickeners: The LST values of salmon and vegetable egg sauce that can be crushed with the gums were statistically compared. The variance between the two groups was examined by F-test. As a result, it was shown that there was no statistically significant difference in any case. Whether the LST value changed after 30 seconds to 5 minutes was investigated using a paired Student-t test. The results are shown in Table 4. In each case, the LST value was statistically significantly higher after 5 minutes than after 30 seconds. It was shown that the viscosity changed over time.

Table 4: Crushable with gums: salmon and vegetable with egg. Statistical comparison of LST values after 30 seconds and 5 minutes.

\begin{tabular}{|c|c|c|c|c|}
\hline \multirow{2}{*}{ Test } & \multicolumn{2}{|c|}{ No Modify } & \multicolumn{2}{|c|}{ After Mixing } \\
\hline & After 30 Seconds & After 5 Minutes & After 30 Seconds & After 5 Minutes \\
\hline F Test & \multicolumn{2}{|c|}{0.23} & \multicolumn{2}{|c|}{0.335} \\
\hline Pair-t test & \multicolumn{2}{|c|}{$0.0001^{* *}$} & \multicolumn{2}{|c|}{$0.0001^{* *}$} \\
\hline F Test & \multicolumn{2}{|c|}{0.244} & \multicolumn{2}{|c|}{0.332} \\
\hline Pair-t test & \multicolumn{2}{|c|}{$0.0001^{* *}$} & \multicolumn{2}{|c|}{$0.0001^{* *}$} \\
\hline F Test & \multicolumn{2}{|c|}{0.214} & \multicolumn{2}{|c|}{0.322} \\
\hline Pair-t test & \multicolumn{2}{|c|}{$0.0001^{* *}$} & \multicolumn{2}{|c|}{$0.0001^{* *}$} \\
\hline
\end{tabular}

Statistical results after 30 seconds and 5 minutes in LST values performed using 8 types of thickeners: Eight types of thickeners added to a commercially available UDF, salmon and vegetable egg sauce that can be crushed with gums The LST values at that time were statistically compared. F-test was performed 30 seconds and 5 minutes after the addition of $1 \mathrm{~g}, 2 \mathrm{~g}$, and $3 \mathrm{~g}$ of thickener, respectively, to examine the dispersion between the two groups. Since the F-test was not statistically significant in all cases, the paired Student-t test was used to compare the LST values after 30 seconds and 5 minutes. The results are shown in Table 5. For all thickeners, the LST value was higher after 5 minutes than after 30 seconds, regardless of the number of grams of thickener added. It was shown that the viscosity became weaker with time.

Table 5: Statistical comparison of LST values after 30 seconds and 5 minutes using different types of thickeners.

\begin{tabular}{|c|c|c|c|c|c|c|c|}
\hline \multirow[b]{2}{*}{ Thickeners } & \multirow[b]{2}{*}{ Test } & \multicolumn{2}{|c|}{ Add Thickener 1g } & \multicolumn{2}{|c|}{ Add Thickener $2 \mathrm{~g}$} & \multicolumn{2}{|c|}{ Add Thickener 3g } \\
\hline & & $\begin{array}{l}\text { After } 30 \\
\text { Seconds }\end{array}$ & $\begin{array}{c}\text { After } 5 \\
\text { Minutes }\end{array}$ & $\begin{array}{l}\text { After } 30 \\
\text { Seconds }\end{array}$ & $\begin{array}{c}\text { After } 5 \\
\text { Minutes }\end{array}$ & $\begin{array}{l}\text { After } 30 \\
\text { Seconds }\end{array}$ & $\begin{array}{c}\text { After } 5 \\
\text { Minutes }\end{array}$ \\
\hline \multirow{2}{*}{ A } & F Test & \multicolumn{2}{|c|}{0.493} & \multicolumn{2}{|c|}{0.364} & \multicolumn{2}{|c|}{0.401} \\
\hline & Pair-t test & \multicolumn{2}{|c|}{$0.0001^{* *}$} & \multicolumn{2}{|c|}{$0.003^{*}$} & \multicolumn{2}{|c|}{$0.001^{*}$} \\
\hline \multirow{2}{*}{ B } & F Test & \multicolumn{2}{|c|}{0.349} & \multicolumn{2}{|c|}{0.499} & \multicolumn{2}{|c|}{0.364} \\
\hline & Pair-t test & \multicolumn{2}{|c|}{$0.0001^{* *}$} & \multicolumn{2}{|c|}{$0.004^{* *}$} & \multicolumn{2}{|c|}{$0.003^{* *}$} \\
\hline \multirow{2}{*}{$\mathrm{C}$} & F Test & \multicolumn{2}{|c|}{0.244} & \multicolumn{2}{|c|}{0.401} & \multicolumn{2}{|c|}{0.235} \\
\hline & Pair-t test & \multicolumn{2}{|c|}{$0.0001^{* *}$} & \multicolumn{2}{|c|}{$0.0001^{* *}$} & \multicolumn{2}{|c|}{$0.0001^{* *}$} \\
\hline \multirow{2}{*}{$\mathrm{D}$} & F Test & \multicolumn{2}{|c|}{0.474} & \multicolumn{2}{|c|}{0.24} & \multicolumn{2}{|c|}{0.433} \\
\hline & Pair-t test & \multicolumn{2}{|c|}{$0.0001^{* *}$} & \multicolumn{2}{|c|}{$0.0001^{* *}$} & \multicolumn{2}{|c|}{$0.0001^{*}$} \\
\hline \multirow{2}{*}{ E } & F Test & \multicolumn{2}{|c|}{0.5} & \multicolumn{2}{|c|}{0.144} & \multicolumn{2}{|c|}{0.224} \\
\hline & Pair-t test & \multicolumn{2}{|c|}{$0.0001^{* *}$} & & & & \\
\hline 5 & F Test & & & & & & \\
\hline 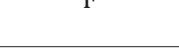 & Pair-t test & & & & & & \\
\hline
\end{tabular}




\begin{tabular}{|c|c|c|c|c|}
\hline \multirow{2}{*}{$\mathrm{G}$} & F Test & 0.439 & 0.245 & 0.086 \\
\cline { 2 - 5 } & Pair-t test & $0.009^{* *}$ & $0.009^{* *}$ & $0.001^{* *}$ \\
\hline \multirow{2}{*}{$\mathrm{H}$} & F Test & 0.5 & 0.391 & 0.289 \\
\cline { 2 - 5 } & Pair-t test & $0.0001^{* *}$ & $0.0001^{* *}$ & $0.048^{*}$ \\
\hline
\end{tabular}

Statistical comparison results of LST value after 30 seconds at each thickener amount using 8 kinds of thickeners: Next, then after 30 seconds between each thickener amount at 8 kinds of thickeners The LST values were statistically compared. There was no statistical difference in the LST values of thickener A and thickener $\mathrm{H}$ when $2 \mathrm{~g}$ of thickener was added and when $3 \mathrm{~g}$ was added. However, the LST value of the other 5 types of thickeners was smaller when $3 \mathrm{~g}$ was added than when $2 \mathrm{~g}$ was added. That is, it was found that the viscosity was strong (Table 6).

Table 6: Statistical comparison of LST values after 30 seconds between thickeners supplemented with eight thickeners.

\begin{tabular}{|c|c|c|c|c|c|c|c|}
\hline \multirow[b]{2}{*}{ Thickeners } & \multirow[b]{2}{*}{ Test } & \multicolumn{2}{|c|}{ After 30 Seconds } & \multicolumn{2}{|c|}{ After 30 Seconds } & \multicolumn{2}{|c|}{ After 30 Seconds } \\
\hline & & \begin{tabular}{c|} 
Add \\
Thickener 1g
\end{tabular} & $\begin{array}{c}\text { Add } \\
\text { Thickener 2g }\end{array}$ & $\begin{array}{c}\text { Add } \\
\text { Thickener 1g }\end{array}$ & $\begin{array}{c}\text { Add } \\
\text { Thickener 3g }\end{array}$ & $\begin{array}{c}\text { Add } \\
\text { Thickener 2g }\end{array}$ & \begin{tabular}{|c|} 
Add \\
Thickener $3 \mathrm{~g}$
\end{tabular} \\
\hline A & F Test & \multicolumn{2}{|c|}{0.132} & \multicolumn{2}{|c|}{0.301} & \multicolumn{2}{|c|}{0.277} \\
\hline & $\begin{array}{l}\text { Pair-t test } \\
\text { Wilcoxon }\end{array}$ & \multicolumn{2}{|c|}{$0.0001^{* *}$} & \multicolumn{2}{|c|}{$0.0001^{* *}$} & \multicolumn{2}{|c|}{0.271} \\
\hline \multirow[t]{2}{*}{ B } & F Test & \multicolumn{2}{|c|}{$0.0014^{*}$} & \multicolumn{2}{|c|}{$0.0001^{* *}$} & \multicolumn{2}{|c|}{$0.031^{*}$} \\
\hline & $\begin{array}{l}\text { Pair-t test } \\
\text { Wilcoxon }\end{array}$ & \multicolumn{2}{|c|}{$0.0001^{* *}$} & \multicolumn{2}{|c|}{$0.0001^{* *}$} & \multicolumn{2}{|c|}{0.182} \\
\hline \multirow[t]{2}{*}{$\mathrm{C}$} & F Test & \multicolumn{2}{|c|}{0.179} & \multicolumn{2}{|c|}{$0.002^{* *}$} & \multicolumn{2}{|c|}{$0.021^{*}$} \\
\hline & $\begin{array}{l}\text { Pair-t test } \\
\text { Wilcoxon }\end{array}$ & \multicolumn{2}{|c|}{$0.0001^{* *}$} & \multicolumn{2}{|c|}{$0.0001^{* *}$} & \multicolumn{2}{|c|}{$0.0001^{* *}$} \\
\hline \multirow[t]{2}{*}{ D } & F Test & \multicolumn{2}{|c|}{$0.013^{*}$} & \multicolumn{2}{|c|}{0.158} & \multicolumn{2}{|c|}{$0.001^{*}$} \\
\hline & $\begin{array}{l}\text { Pair-t test } \\
\text { Wilcoxon }\end{array}$ & \multicolumn{2}{|c|}{0.452} & \multicolumn{2}{|c|}{$0.0001^{* *}$} & \multicolumn{2}{|c|}{$0.0001^{* *}$} \\
\hline \multirow[t]{2}{*}{ E } & F Test & \multicolumn{2}{|c|}{0.114} & \multicolumn{2}{|c|}{0.172} & \multicolumn{2}{|c|}{0.387} \\
\hline & $\begin{array}{l}\text { Pair-t test } \\
\text { Wilcoxon }\end{array}$ & 0.04 & $5^{* *}$ & 0.0 & $01^{* *}$ & 0.00 & $01^{* *}$ \\
\hline $\mathrm{F}$ & F Test & 0.1 & & 0.0 & & & 93 \\
\hline & $\begin{array}{l}\text { Pair-t test } \\
\text { Wilcoxon }\end{array}$ & 0.00 & & 0.00 & $1^{* *}$ & 0.0 & $99^{* *}$ \\
\hline G & F Test & 0.00 & $01^{* *}$ & 0.00 & $1^{* *}$ & & 56 \\
\hline & $\begin{array}{l}\text { Pair-t test } \\
\text { Wilcoxon }\end{array}$ & 0.00 & $01^{* *}$ & 0.00 & $1^{* *}$ & & 67 \\
\hline $\mathrm{H}$ & F Test & 0.0 & & 0.1 & & & $31^{*}$ \\
\hline & $\begin{array}{l}\text { Pair-t test } \\
\text { Wilcoxon }\end{array}$ & 0.00 & $01^{* *}$ & 0.00 & $1^{* *}$ & & 87 \\
\hline
\end{tabular}

Statistical comparison results of LST value after 5 minutes between each thickener amount using 8 kinds of thickeners: Similarly, 5 minutes after addition of each thickener amount in 8 kinds of thickeners The LST values were statistically compared. There was no statistical difference in the LST values of the thickeners D and G when $1 \mathrm{~g}$ of the thickener was added and when $2 \mathrm{~g}$ of the thickener was added. However, it was found that the LST value of the other 6 types of thickeners was smaller when $2 \mathrm{~g}$ was added than when $1 \mathrm{~g}$ was added, that is, the viscosity was stronger (Table 7).

Table 7: Statistical comparison of LST values after 5 minutes between thickeners supplemented with eight thickeners.

\begin{tabular}{|c|c|c|c|c|c|c|c|}
\hline \multirow[b]{2}{*}{ Thickeners } & \multirow[b]{2}{*}{ Test } & \multicolumn{2}{|c|}{ After 30 Seconds } & \multicolumn{2}{|c|}{ After 30 Seconds } & \multicolumn{2}{|c|}{ After 30 Seconds } \\
\hline & & $\begin{array}{c}\text { Add } \\
\text { Thickener 1g }\end{array}$ & $\begin{array}{c}\text { Add } \\
\text { Thickener 2g }\end{array}$ & $\begin{array}{c}\text { Add } \\
\text { Thickener 1g }\end{array}$ & $\begin{array}{c}\text { Add } \\
\text { Thickener } \mathbf{3 g}\end{array}$ & $\begin{array}{c}\text { Add } \\
\text { Thickener 2g }\end{array}$ & $\begin{array}{c}\text { Add } \\
\text { Thickener } \mathbf{3 g}\end{array}$ \\
\hline \multirow{2}{*}{ A } & F Test & \multicolumn{2}{|c|}{0.227} & \multicolumn{2}{|c|}{0.227} & \multicolumn{2}{|c|}{0.498} \\
\hline & Pair-t test Wilcoxon & \multicolumn{2}{|c|}{$0.0001^{* *}$} & \multicolumn{2}{|c|}{$0.0001^{* *}$} & \multicolumn{2}{|c|}{0.31} \\
\hline \multirow{2}{*}{ B } & F Test & \multicolumn{2}{|c|}{$0.0001^{* *}$} & \multicolumn{2}{|c|}{$0.0001^{* *}$} & \multicolumn{2}{|c|}{$0.031^{*}$} \\
\hline & Pair-t test Wilcoxon & \multicolumn{2}{|c|}{$0.0001^{* *}$} & \multicolumn{2}{|c|}{$0.0001^{* *}$} & \multicolumn{2}{|c|}{0.078} \\
\hline \multirow{2}{*}{$\mathrm{C}$} & F Test & \multicolumn{2}{|c|}{0.34} & \multicolumn{2}{|c|}{$0.002^{* *}$} & \multicolumn{2}{|c|}{$0.007^{* *}$} \\
\hline & Pair-t test Wilcoxon & \multicolumn{2}{|c|}{$0.0001^{* *}$} & \multicolumn{2}{|c|}{$0.0001^{* *}$} & \multicolumn{2}{|c|}{$0.0001^{* *}$} \\
\hline
\end{tabular}




\begin{tabular}{|c|c|c|c|c|}
\hline \multirow{2}{*}{ D } & F Test & 0.051 & 0.22 & $0.009^{* *}$ \\
\cline { 2 - 5 } & Pair-t test Wilcoxon & 0.84 & $0.0001^{* *}$ & $0.0001^{* *}$ \\
\hline \multirow{2}{*}{ E } & F Test & 0.013 & 0.424 & $0.020^{*}$ \\
\cline { 2 - 5 } & Pair-t test Wilcoxon & 0.187 & $0.0001^{* *}$ & $0.0001^{* *}$ \\
\hline \multirow{2}{*}{ F } & F Test & 0.219 & $0.011^{* *}$ & 0.05 \\
\cline { 2 - 5 } & Pair-t test Wilcoxon & $0.002^{* *}$ & $0.0001^{* *}$ & $0.009^{* *}$ \\
\hline \multirow{2}{*}{ G } & F Test & $0.0001^{* *}$ & $0.0001^{* *}$ & 0.373 \\
\cline { 2 - 5 } & Pair-t test Wilcoxon & $0.0001^{* *}$ & $0.0001^{* *}$ & 0.534 \\
\hline \multirow{2}{*}{ H } & F Test & $0.001^{*}$ & $0.050^{*}$ & 0.056 \\
\cline { 2 - 5 } & Pair-t test Wilcoxon & $0.0001^{* *}$ & $0.0001^{* *}$ & 0.901 \\
\hline
\end{tabular}

In addition, there was no statistically significant difference in the thickeners $A, B, G$, and $H$ between the case where $2 \mathrm{~g}$ of the thickener was added and the case where $3 \mathrm{~g}$ of the thickener was added. However, it can be seen that the LST value of the other four types of thickeners is smaller when $3 \mathrm{~g}$ is added than when $2 \mathrm{~g}$ is added, that is, the viscosity is stronger. Statistical comparison results of $1 \mathrm{~g}$ and $3 \mathrm{~g}$ additions of 8 types of thickeners showed that the LST value was smaller, that is, the viscosity was stronger when $3 \mathrm{~g}$ was added than when all $1 \mathrm{~g}$ was added.
Statistical comparison results 30 seconds after LST after addition of $1 \mathrm{~g}$ of 8 types of thickeners (multiple comparison by Schaffer method; lateral direction): Table 8 shows the statistical comparison results after 30 seconds of LST after adding $1 \mathrm{~g}$ of 8 types of thickeners. It was found that the thickeners C, E, and G had a significantly higher LST value and a lower viscosity than the thickener A.

Table 8: Statistical comparison of LST values 30 seconds after $1 \mathrm{~g}$ of each thickener was added. (Multiple comparison by Scheffe's method: Horizontal direction, Established higher).

\begin{tabular}{|c|c|c|c|c|c|c|c|c|}
\hline & $\mathbf{A}$ & B & C & D & $\mathbf{E}$ & $\mathbf{F}$ & $\mathbf{G}$ & $\mathbf{H}$ \\
\hline A & --------- & 0.987 & $0.0001^{* *}$ & 0.278 & 0.031 & 1.000 & $0.001^{* *}$ & 0.463 \\
\hline B & 0.987 & --------- & $0.001^{* *}$ & 0.855 & 0.329 & 0.954 & $0.042^{*}$ & 0.954 \\
\hline $\mathrm{C}$ & $0.0001^{* *}$ & $0.001^{* *}$ & --------- & 0.166 & 0.668 & $0.0001^{* *}$ & 0.985 & 0.077 \\
\hline D & 0.278 & 0.855 & 0.166 & ---------. & 0.993 & 0.186 & 0.743 & 1.000 \\
\hline E & $0.031^{*}$ & 0.329 & 0.668 & 0.993 & ---------- & $0.014^{*}$ & 0.993 & 0.96 \\
\hline $\mathrm{F}$ & 1.000 & 0.954 & $0.0001^{* *}$ & 0.166 & $0.014^{*}$ & ---------- & $0.0001^{* *}$ & 0.311 \\
\hline G & $0.001^{* *}$ & $0.042^{*}$ & 0.985 & 0.743 & 0.993 & $0.0001^{* *}$ & ---------- & 0.545 \\
\hline $\mathrm{H}$ & 0.436 & 0.954 & 0.077 & 1.000 & 0.96 & 0.311 & 0.545 & --------- \\
\hline
\end{tabular}

Statistical comparison results 5 minutes after LST after addition of $1 \mathrm{~g}$ of 8 types of thickeners (multiple comparison by Schaffer method; lateral direction): Table 9 shows the statistical comparison results after 5 minutes of LST after adding $1 \mathrm{~g}$ of 8 types of thickeners. It was found that the thickeners C, D, E, and G had a significantly higher LST value and a lower viscosity than the thickener A.

Table 9: Statistical comparison of LST values 5 minutes after $1 \mathrm{~g}$ of each thickener was added. (Multiple comparison by Scheffe's method: Horizontal direction, Established higher).

\begin{tabular}{|c|c|c|c|c|c|c|c|c|}
\hline & $\mathbf{A}$ & B & $\mathbf{C}$ & D & $\mathbf{E}$ & $\mathbf{F}$ & $\mathbf{G}$ & $\mathbf{H}$ \\
\hline A & -------- & 0.982 & $0.0001^{* *}$ & $0.014^{*}$ & $0.0001^{* *}$ & 0.999 & $0.0001^{* *}$ & 0.088 \\
\hline B & 0.982 & -------- & $0.0001^{* *}$ & 0.232 & $0.005^{* *}$ & 1.000 & $0.0001^{* *}$ & 0.6 \\
\hline $\mathrm{C}$ & $0.0001^{* *}$ & $0.0001^{* *}$ & -------- & 0.088 & 0.760 & $0.0001^{* *}$ & 0.98 & $0.014^{*}$ \\
\hline D & $0.014^{*}$ & 0.232 & 0.088 & --------- & 0.937 & 0.103 & 0.609 & 0.999 \\
\hline $\mathrm{E}$ & $0.0001^{* *}$ & $0.005^{* *}$ & 0.760 & 0.937 & ---------- & $0.001^{*}$ & 0.999 & 0.648 \\
\hline $\mathrm{F}$ & 0.999 & 1.000 & $0.0001^{* *}$ & 0.103 & $0.001^{* *}$ & ---------- & $0.0001^{* *}$ & 0.370 \\
\hline G & $0.0001^{* *}$ & $0.0001^{* *}$ & 0.980 & 0.608 & 0.999 & $0.0001^{* *}$ & --------- & 0.238 \\
\hline $\mathrm{H}$ & 0.088 & 0.6 & $0.014^{* *}$ & 0.999 & 0.648 & 0.370 & 0.238 & ------- \\
\hline
\end{tabular}

Statistical comparison results 30 seconds after LST after addition of $\mathbf{2 g}$ of 8 types of thickeners (multiple comparison by Schaffer method; lateral direction): Table 10 shows the statistical comparison results after 30 seconds of LST after adding
$2 \mathrm{~g}$ of 8 types of thickeners. It was found that the thickeners D and $\mathrm{E}$ had a significantly higher LST value and a lower viscosity than the thickener A. 
Table 10: Statistical comparison of LST values 30 seconds after $2 \mathrm{~g}$ of each thickener was added. (Multiple comparison by Scheffe's method: Horizontal direction, Established higher).

\begin{tabular}{|c|c|c|c|c|c|c|c|c|}
\hline & $\mathbf{A}$ & B & C & D & $\mathbf{E}$ & $\mathbf{F}$ & $\mathbf{G}$ & $\mathbf{H}$ \\
\hline A & ------ & 0.999 & 0.799 & $0.0001^{* *}$ & $0.0001^{* *}$ & 0.991 & 0.999 & 0.999 \\
\hline B & 0.999 & ------- & 0.516 & $0.0001^{* *}$ & $0.0001^{* *}$ & 0.913 & 1.000 & 1.000 \\
\hline $\mathrm{C}$ & 0.799 & 0.516 & ------ & 0.76 & 0.067 & 0.998 & 0.456 & 0.546 \\
\hline D & $0.0001^{* *}$ & $0.0001^{* *}$ & 0.076 & ------- & 1.000 & $0.007^{* *}$ & $0.0001^{* *}$ & $0.0001^{* *}$ \\
\hline $\mathrm{E}$ & $0.0001^{* *}$ & $0.0001^{* *}$ & 0.067 & 1.000 & -------- & $0.006^{* *}$ & $0.0001^{* *}$ & $0.0001^{* *}$ \\
\hline $\mathrm{F}$ & 0.991 & 0.913 & 0.998 & $0.007^{* *}$ & $0.006^{* *}$ & -------- & 0.881 & 0.927 \\
\hline G & 1.000 & 1.000 & 0.456 & $0.0001^{* *}$ & $0.0001^{* *}$ & 0.881 & ------- & 1.000 \\
\hline $\mathrm{H}$ & 1.000 & 1.000 & 0.545 & $0.0001^{* *}$ & $0.0001^{* *}$ & 0.927 & 1.000 & ------- \\
\hline
\end{tabular}

Statistical comparison results 5 minutes after LST after addition of $2 \mathrm{~g}$ of 8 types of thickeners (multiple comparison by Schaffer method; lateral direction): Table 11 shows the statistical comparison results after 5 minutes of LST after adding
$2 \mathrm{~g}$ of 8 types of thickeners. It was found that the thickeners D and $\mathrm{E}$ had a significantly higher LST value and a lower viscosity than the thickener A.

Table 11: Statistical comparison of LST values 5 minutes after $2 \mathrm{~g}$ of each thickener was added. (Multiple comparison by Scheffe's method: Horizontal direction, Established higher).

\begin{tabular}{|c|c|c|c|c|c|c|c|c|}
\hline & $\mathbf{A}$ & B & C & D & $\mathbf{E}$ & $\mathbf{F}$ & $\mathbf{G}$ & $\mathbf{H}$ \\
\hline A & -------- & 1.000 & 0.121 & $0.0001^{* *}$ & $0.0001^{* *}$ & 0.874 & 1.000 & 1.000 \\
\hline B & 1.000 & -------- & 1.344 & $0.0001^{* *}$ & $0.0001^{* *}$ & 0.985 & 1.000 & 0.999 \\
\hline $\mathrm{C}$ & 0.121 & 0.344 & -------- & $0.043^{*}$ & $0.022^{*}$ & 0.905 & 0.197 & 0.079 \\
\hline D & $0.0001^{* *}$ & $0.0001^{* *}$ & $0.043^{*}$ & -------- & 1.000 & $0.0001^{* *}$ & $0.0001^{* *}$ & $0.0001^{* *}$ \\
\hline $\mathrm{E}$ & $0.0001^{* *}$ & $0.0001^{* *}$ & $0.022^{*}$ & 1.000 & ------- & $0.0001^{* *}$ & $0.0001^{* *}$ & $0.0001^{* *}$ \\
\hline $\mathrm{F}$ & 0.874 & 0.985 & 0.905 & $0.0001^{* *}$ & $0.0001^{* *}$ & -------- & 0.942 & 0.796 \\
\hline G & 1.000 & 1.000 & 0.197 & $0.0001^{* *}$ & $0.0001^{* *}$ & 0.942 & --------- & 1.000 \\
\hline $\mathrm{H}$ & 1.000 & 0.999 & 0.079 & $0.0001^{* *}$ & $0.0001^{* *}$ & 0.796 & 1.000 & ------- \\
\hline
\end{tabular}

Statistical comparison results 30 seconds after LST after addition of $3 \mathrm{~g}$ of 8 types of thickeners (multiple comparison

statistical comparison results after 30 seconds of LST after adding by Schaffer method; lateral direction): Table 12 shows the

$3 \mathrm{~g}$ of 8 types of thickeners. All were not statistically significant.

Table 12: Statistical comparison of LST values 30 seconds after $3 \mathrm{~g}$ of each thickener was added. (Multiple comparison by Scheffe's method: Horizontal direction, Established higher).

\begin{tabular}{|c|c|c|c|c|c|c|c|c|}
\hline & $\mathbf{A}$ & B & C & D & $\mathbf{E}$ & F & G & $\mathbf{H}$ \\
\hline A & -------- & 1.000 & 0.995 & 0.983 & 1.000 & 0.936 & 0.987 & 1.000 \\
\hline B & 1.000 & -------- & 1.000 & 1.000 & 0.995 & 0.995 & 1.000 & 0.999 \\
\hline $\mathrm{C}$ & 0.995 & 1.000 & -------- & 1.000 & 0.962 & 1.000 & 1.000 & 0.990 \\
\hline D & 0.983 & 1.000 & 1.000 & ---------- & 0.914 & 1.000 & 1.000 & 0.968 \\
\hline E & 1.000 & 0.995 & 0.962 & 0.914 & ---------- & 0.800 & 0.926 & 1.000 \\
\hline $\mathrm{F}$ & 0.936 & 0.995 & 1.000 & 1.000 & 0.800 & ----------- & 1.000 & 0.901 \\
\hline G & 0.987 & 1.000 & 1.000 & 1.000 & 0.926 & 1.000 & --------- & 0.974 \\
\hline $\mathrm{H}$ & 1.000 & 0.999 & 0.990 & 0.968 & 1.000 & 0.901 & 0.974 & --------- \\
\hline
\end{tabular}

Statistical comparison results 5 minutes after LST after addition of $3 \mathrm{~g}$ of 8 types of thickeners (multiple comparison by Schaffer method; lateral direction): Table 13 shows the statistical comparison results after 5 minutes of LST after adding $3 \mathrm{~g}$ of 8 types of thickeners. All were not statistically significant. 
Table 13: Statistical comparison of LST values 5 minutes after $3 \mathrm{~g}$ of each thickener was added. (Multiple comparison by Scheffe's method: Horizontal direction, Established higher).

\begin{tabular}{|c|c|c|c|c|c|c|c|c|}
\hline & $\mathbf{A}$ & B & C & D & $\mathbf{E}$ & $\mathbf{F}$ & $\mathbf{G}$ & $\mathbf{H}$ \\
\hline A & -------- & 1.000 & 1.000 & 1.000 & 0.995 & 0.994 & 1.000 & 1.000 \\
\hline B & 1.000 & --------- & 1.000 & 1.000 & 0.997 & 0.999 & 1.000 & 0.999 \\
\hline $\mathrm{C}$ & 1.000 & 1.000 & -------- & 1.000 & 0.981 & 0.999 & 1.000 & 0.999 \\
\hline D & 1.000 & 1.000 & 1.000 & -------- & 0.998 & 0.984 & 1.000 & 1.000 \\
\hline E & 0.995 & 0.997 & 0.981 & 0.998 & ------- & 0.771 & 0.994 & 1.000 \\
\hline $\mathrm{F}$ & 0.994 & 0.999 & 0.999 & 0.984 & 0.771 & --------- & 0.995 & 0.939 \\
\hline G & 1.000 & 1.000 & 1.000 & 1.000 & 0.994 & 0.995 & -------- & 1.000 \\
\hline $\mathrm{H}$ & 1.000 & 0.999 & 0.999 & 1.000 & 1.000 & 0.939 & 1.000 & -------. \\
\hline
\end{tabular}

\section{DISCUSSION}

Using 8 types of thickeners, add $1 \mathrm{~g}, 2 \mathrm{~g}$, and $3 \mathrm{~g}$ of thickeners to the salmon and vegetable egg sauces, which are the vegetable menus in the category that can be crushed with toothpaste, which is a commercially available universal design food. And compared the LST. As a result, there was a tendency for the LST value to be higher and the viscosity to be lower after 30 seconds and 5 minutes for the KST value of each thickener. Some thickeners were statistically significantly less viscous. In addition, the larger the amount of thickener added, the lower the LST value and the higher the viscosity. It was statistically significantly higher depending on the thickener. In addition, eight types of thickeners were compared using multiple comparisons by Scheffe's method. As a result, it was shown that the thickener A was statistically significantly highly viscous regardless of whether $1 \mathrm{~g}$ was added or $2 \mathrm{~g}$ was added. However, when $3 \mathrm{~g}$ of the thickener was added, there was no difference in viscosity between the eight types of thickeners.

In order to provide a safe and secure meal, the viscosity must be stable. For that purpose, the combination of diet or food and thickener is important. It was found that the thickener A in this food has a more stable viscosity than other thickeners. However, in foods, when there is a lot of water, a lot of protein, and a lot of carbohydrates, it is necessary to select and use a suitable thickener properly.

In addition, although the viscosity was measured at room temperature (around 30 degrees Celsius) this time, it is necessary to select a thickener suitable for the meal depending on the temperature at the time of serving, and it may be necessary to further change the addition amount. Temperature is related to deliciousness, but depending on the swallowing function of the eater, it may be provided at a temperature lower than body temperature (around 10 degrees) to prevent burns in the oral cavity and esophagus. This is because the swallowing reflex is unlikely to occur at the same temperature as body temperature.

In order to prevent sarcopenia [1,2] and flail [3-9] due to malnutrition and to prevent aspiration pneumonia, it is necessary to add viscosity to drinks [10-13] and liquid meals [14-16], using a thickener. I would like to continue my research and consider combinations of thickeners that are suitable for foods.

\section{CONCLUSION}

Comparing the viscosities of thickeners with the same amount added to foods, the difference in viscosity becomes clear when the amount added is smaller, so it is necessary to consider compatibility with foods. All of the eight types of thickeners used this time are mainly composed of dextrin, but depending on the combination of other food materials, they were added to the same commercially available universal design food, but in multiple thickeners Since there is a statistically significant difference in the LST value, it is necessary to confirm the LST value when providing it to the eating target.

This time, the LST value was measured at room temperature (around 20 degrees), but if the temperature is kept above 60 degrees when serving meals, the viscosity of the food value may change, so it is necessary to change the temperature for comparison. I think. It is a future task.

\section{ACKNOWLEDGEMENT}

This research was conducted by research and education expenses of Naomi Katayama, Nagoya Women's University, Nagoya City, Japan.

\section{REFERENCES}

1. SilvaNeto LS, Karnikowiski MG, Tavares AB, Lima RM (2012) Association between sarcopenia, sarcopenic obesity, muscle strength and quality of life variables in elderly women. Rev Bras Fisioter 16(5): 360-367.

2. Go SW, Cha YH, Lee JA, Park HS (2013) Association between sarcopenia, bone density, and health-related quality of life in Korean men. Korean J Fam Med 34(4): 281-288.

3. Rizzoli R, Reginster JY, Arnal JF, Bautmans I, Beaudart C, et al. (2013) Quality of life in sarcopenia and frailty. Calcif Tissue Int 93(2): 101-120.

4. Fried LP, Ferrucci L, Darer J, Williamson JD, Anderson G (2004) Untangling the concepts of disability, frailty, and comorbidity: Implications for improved targeting and care. J Gerontol A Biol Sci Med Sci 59(3): 255-263.

5. Ferrucci L, Guralnik JM, Studenski S, Fried LP, Cutler GB, et al. (2004) Designing randomized, controlled trials aimed at preventing or delaying functional decline and disability in frail, older persons: A consensus report. J am GeriatrSoc 52(4): 625-634.

6. Bandeen-Roche K, Xue QL, Ferrucci L, Walston J, Guralnik JM, et al. (2006) Phenotype of frailty: characterization in the women's health and aging studies. J Gerontol A Biol Sci Med Sci 61(3): 262-266.

7. Fried LP, Tangen CM, Walston J, Cardiovascular Health Study Collaborative Research Group(2001) Frailty in older adults: Evidence for phenotype evidence for a phenotype. J Gerontol A BiolSci Med Sci 56(3): M146-156.

8. Ensrud KE, Ewing SK, Taylor BC, Fink HA, Cawthon PM, et al. (2008) Comparison of 2 frailty indexes for prediction of falls, disability, fractures, and death in older women. Arch Intern Med 168(4): 382-389.

9. Malafarina V, Uriz-Otano F, Iniesta R, Gil-Guerrero L (2013) Effectiveness of nutritional supplementation on muscle mass in treatment of sarcopenia in old age: A systematic review. J Am Med Dir Assoc 14(1): 10-17. 
10. Claire de SA, Graham S, Kayashita J (2014) Comparison of 2 tests used for the classification of food thickeners in the management of dysphagia. Gums and Stabilizers for the Food Industry 17.

11. Leder SB, Judson BL, Sliwinski E, Madson L (2013) Promoting safe swallowing when puree is swallowed without aspiration, but thin liquid is aspirated: Nectar is enough. Dysphagia 28(1): 58-62.

12. Murray J, Miller M, Doeltgen S, Scholten I (2014) Intake of thickened liquids by hospitalized adults with dysphagia after stroke. International Journal of Speech-Language Pathology 16(5): 486-494.

13. Shoko K, Megumi O, Naomi K (2019) Research on the combination of commercially available thickeners and nutritional supplemental drink Aiming at the care food that can be done in the general family. Advances in Nutrition and Food science 1: 1-9.
14. Naomi K, Mayumi H, Shoko K (2020) Research on the combination of commercially available thickeners and commercially available nursing food - By using universal design food: UDF (Do not have to bite). Global Journal of Medical Research 20(11): 49-53.

15. Mayumi H, Shoko K, Naomi K (2020) Research on the combination of commercially available thickeners and commercially available nursing food - Universal design food: UDF (can be crushed with gums). Global Journal of Medical Research 20(11): 11-15.

16. Mayumi H, Shoko K, Naomi K (2020) Research on the combination of commercially available thickeners and commercially available nursing food - Aiming for viscosity adjustment that can be done at home. Global Journal of Medical Research 20(11): 43-47. 